\title{
Does proactive green logistics management improve business performance? A case of Chinese logistics enterprises
}

\author{
Yongrok Choi ${ }^{1}$ and Ning Zhang ${ }^{2 *}$ \\ ${ }^{1}$ Department of International Trade, Inha University, Incheon 402-751, South Korea. \\ ${ }^{2}$ School of Management, Shandong Women's University, Jinan 250300, P. R. China.
}

Accepted 6 May, 2011

\begin{abstract}
Sustainability is a subject of growing interest in business and environmental management. Many previous studies have emphasized the trade-off between economic activities such as manufacturing and its effect on the environment. Moreover, previous studies have mainly focused on manufacturing enterprises; however, no study has yet to cover the logistics sector. This study fills these gaps by testing the causal relationship between proactive green management and the sustainable performance of logistics enterprise in China. In addition, when compared with previous literature that discusses the partial relationship between environmental variables and firm performance, this study synthesizes the factors of green awareness and green strategy that may influence green logistics management in a total systematic structural equation model (SEM). SEM has an advantage in examining the causal relationship between green logistics practice and its business performance. The result shows that green logistics practice has a positive impact on sustainable business performance. This impact is composed of both a positive financial and environmental performance, while the relationship between green awareness and business performance and the influence of green strategy on business performance is not significant.
\end{abstract}

Keywords: Green logistics management, structural equation model (SEM), business performance, Chinese logistics enterprises.

\section{INTRODUCTION}

As the global economy integrates countries across the world, the paradigm shift from manufacturing to assembling has emphasized the importance of logistics. In the era of cooperative business by assembling, businesses have functioned with many partners. Thus, logistics has been widely used to describe integrated practice among the networks of transportation, storage, and handling of products as they move from material source through the supply chain system to the final point of sale or consumption, which is the key determinant of business performance (Choi, 2011). As Zhou et al. (2008) indicated, environmental issues are increasingly important; research on both the macro- and micro-level touch on the environmental issues in many ways. He et al. (2009) also suggested the importance of energy savings in the

${ }^{\star}$ Corresponding author. E-mail: zn928zn@hotmail.com. Tel: +82 32 8607760. Fax: +82 328769328. transportation of products.

Prior to the 1980s, the environmental initiatives for logistics enterprises were typically temporary and passive in response to government regulations. Recently, public concern began to increase over environmental issues, and new international standards were introduced, including ISO 14001 and ISO 26000, in order to accredit enterprises' green practices (Lee, 2009). Customers became more sensitive about whether suppliers had the required environmental accreditation (Lee and Kim, 2009). As Murphy and Poist (1995) indicated in their survey studies, 61 percent of U.S. firms had formal or written environmental strategies. Thus, if the enterprises plan to extract more value by adopting green management, they must make environmental management a strategic element of their business performance.

Green logistics is a relatively young but rapidly evolving subject. In fact, Aronsson and Brodin (2003) found that only 2.2 percent of papers related to logistics addressed environmental issues. Even if many enterprises set off 
the green awareness movement by adopting corporate social responsibility (CSR) programs into their business plans, they would still lack the integrated practice regarding the green logistics network. With the increasing volume of integrated practices on green logistics, now is the time to answer the question whether there is a tradeoff between green logistics practice and business performance. Will firms who pay more attention to the practice of green logistics attract more business and achieve greater environmental performance? This question is not new, and similar efforts have been made to empirically examine the relationship between green management practices on business performance (Huang and Shih, 2010; Chang and Fong, 2010). Our paper shall extend this approach to the field of logistics enterprises as the network manager of all manufacturing processes.

Previous studies have suffered from some limitations as discussed further. First, previous literature has highlighted only a partial relationship between green management and its performance. For instance, some studies have analyzed a direct relationship between environmental management and environmental performance (Szymanski and Tiwari, 2004; Zhu and Sarkis, 2004). Other studies have tested the causality between environmental management and financial performance (Wanger et al., 2002; Wanger, 2005). This paper integrates these two factors into a more comprehensive model; we consider the total effect between the environmental and business variables, as well as their performance. Environmental (green) awareness and a proactive green strategy were integrated into the model to test the relationship between these physical and practical issues of green management and its sustainable performance. Our discussion about the sustainable performance includes information about the financial performance as well as the environmental performance.

Secondly, while previous studies mainly focused on manufacturing enterprises with general environmental variables, no studies have researched the logistics sector with special green logistics management variables. This paper fills this gap to analyze the relationship between green logistics management and its performance in the logistics sectors of China which is the largest logistics market worldwide.

Thirdly, most studies are based on the regression analysis in their methodological approaches. Even if this direct causality explains the role of green issues easily and clearly, it still lacks the integrated multi-dimensional or step-wise implication of the empirical results. Therefore, the paper introduces the structural equation model (SEM) to correct this methodological bias.

\section{LITERATURE REVIEW}

The more field-oriented empirical question is whether improved environmental management could lead to better business performance. A large body of literature has been devoted to empirically test the link between green management and business performance. However, a general consensus has not been reached (Zeng et al., 2010). Some authors argue that proactive environmental management is simply a tool to help enterprises form better business performance, resulting in these two input and output variables, which create a positive relationship (Huang and Shih, 2010; Wu et al., 2010; Zeng et al., 2010). By placing more emphasis on environmental management, enterprises may reduce costs and increase revenues (Ambec and Lanoie, 2008). Other studies, however, conclude that environmental practices and initiatives involve higher costs and fewer benefits, and they may even create a negative relationship between environmental management and business performance (Cordeiro and Sarkis, 1997; Link and Naveh, 2006; Wanger, 2005).

As shown in Table 1, recent studies on the relationship between green management and business performance have made conclusions that have contradicting implications on each other. The conclusions may come from the different set of variables and/or the methodological bias as shown in Table 1. Most studies have employed a multiple regression analysis to test the relationship; one disadvantage of the multiple regression analysis is that is can only provide partial information. In addition, all studies have focused on environmental management in general, especially in manufacturing industries. None of the studies have touched on the green logistics issues in manufacturing or the role of logistics enterprises.

To synthesize all of these approaches, we use the structural equation model (SEM) to analyze the causal relationship between green logistics management and the business performance of logistics enterprises in China. SEM is a technique that involves multiple regression analysis, path analysis, and confirmatory factor analysis (Hussey and Eagan, 2007). SEM uses both structure equations and measurement equations. The structure equations depict the relationship among the latent variables, which shows the qualitative relationship between exogenous and endogenous variables in the multiple regression analysis. The measurement equations map the relationship between the latent variables and observable variables using a confirmatory factor analysis (CFA) (Chen and Li, 2010).

\section{Hypotheses and model}

Based on the comparison of previous research studies as shown in Table 1, we shall discuss the various research hypotheses and models.

\section{Enterprise size hypothesis}

López-Gamero et al. (2009) found that larger firms are more likely to integrate environmental strategies into their 
Table 1. Comparisons on the previous literature.

\begin{tabular}{|c|c|c|c|c|c|}
\hline Authors & Study object & Green variables & $\begin{array}{l}\text { Performance } \\
\text { variables }\end{array}$ & Method & $\begin{array}{l}\text { Relationship } \\
\text { between findings }\end{array}$ \\
\hline $\begin{array}{l}\text { Hart and Ahuja } \\
\text { (1996) }\end{array}$ & $\begin{array}{l}127 \text { U.S. firms } \\
\text { in SIC }\end{array}$ & Emission reduction data & $\begin{array}{l}\text { ROA, ROE, } \\
\text { ROS }\end{array}$ & Regression & Positive relationship \\
\hline $\begin{array}{l}\text { Russo and } \\
\text { Fouts (1997) }\end{array}$ & 243 U.S. firms & $\begin{array}{l}\text { Environmental ratings, } \\
\text { compliance, waste reduction }\end{array}$ & ROA & Regression & Positive relationship \\
\hline $\begin{array}{l}\text { Christmann } \\
(2000)\end{array}$ & $\begin{array}{l}88 \text { U.S. chemical } \\
\text { companies }\end{array}$ & $\begin{array}{l}\text { Pollution prevention } \\
\text { technology }\end{array}$ & $\begin{array}{l}\text { Cost } \\
\text { advantage }\end{array}$ & Regression & Positive relationship \\
\hline $\begin{array}{l}\text { Wanger et al. } \\
(2002)\end{array}$ & $\begin{array}{l}37 \text { European } \\
\text { firms }\end{array}$ & $\begin{array}{l}\text { Environmental index } \\
\mathrm{SO}^{2} \text { emissions, NOx } \\
\text { emissions and COD } \\
\text { emissions }\end{array}$ & $\begin{array}{l}\text { ROS, ROE, } \\
\text { ROCE }\end{array}$ & $\begin{array}{l}\text { Simultaneous } \\
\text { equation }\end{array}$ & $\begin{array}{l}\text { Negative } \\
\text { relationship }\end{array}$ \\
\hline $\begin{array}{l}\text { Melnyk et al. } \\
\text { (2003) }\end{array}$ & $\begin{array}{l}1222 \\
\text { manufacturing firms }\end{array}$ & $\begin{array}{l}\text { State of the environmental } \\
\text { management }\end{array}$ & $\begin{array}{l}\text { Corporate } \\
\text { performance } \\
\text { index }\end{array}$ & Regression & Positive relationship \\
\hline $\begin{array}{l}\text { Menguc and } \\
\text { Ozanne (2005) }\end{array}$ & $\begin{array}{l}140 \text { Australian } \\
\text { manufacturing firms }\end{array}$ & $\begin{array}{l}\text { Higher natural environment } \\
\text { orientation (NEO) }\end{array}$ & $\begin{array}{l}\text { Market share, } \\
\text { sales growth, } \\
\text { profit }\end{array}$ & Path analysis & Partial relationship \\
\hline $\begin{array}{l}\text { Link and } \\
\text { Naveh (2006) }\end{array}$ & $\begin{array}{l}77 \text { Israel ISO } \\
14001 \text { certified } \\
\text { organizations }\end{array}$ & $\begin{array}{l}\text { ISO } 14001 \text { policies, } \\
\text { emission, use of recycled } \\
\text { materials }\end{array}$ & $\begin{array}{l}\text { Gross profit } \\
\text { margin }\end{array}$ & Regression & No relationship \\
\hline Wahba (2008) & 156 Egyptian firms & ISO 14001 certification & Tobin's q & $\begin{array}{l}\text { Correlation } \\
\text { and } \\
\text { regression }\end{array}$ & Positive relationship \\
\hline $\begin{array}{l}\text { Wu et al. } \\
(2010)\end{array}$ & 238 Taiwan IT firms & $\begin{array}{l}\text { Decrease of consumption } \\
\text { for hazardous materials and } \\
\text { environmental accidents }\end{array}$ & $\begin{array}{l}\text { Operational } \\
\text { cost and } \\
\text { training cost }\end{array}$ & Regression & Positive relationship \\
\hline $\begin{array}{l}\text { Huang and } \\
\text { Shih (2010) }\end{array}$ & $\begin{array}{l}332 \text { Taiwan } \\
\text { manufacturing firms }\end{array}$ & Environmental knowledge & $\begin{array}{l}\text { Environmental } \\
\text { performance, } \\
\text { financial } \\
\text { performance }\end{array}$ & $\begin{array}{l}\text { Structural } \\
\text { equation } \\
\text { Model }\end{array}$ & Positive relationship \\
\hline $\begin{array}{l}\text { Zeng et al. } \\
(2010)\end{array}$ & $\begin{array}{l}125 \text { Chinese } \\
\text { manufacturing firms }\end{array}$ & Cleaner production & $\begin{array}{l}\text { Saving, } \\
\text { profit, brand }\end{array}$ & $\begin{array}{l}\text { Structural } \\
\text { equation } \\
\text { Model }\end{array}$ & Positive relationship \\
\hline
\end{tabular}


business practices than smaller firms. The firm size may reflect the legitimacy principle or the scale of the enterprise that is visible to the public. A large enterprise may be either seen as a sector leader, or it is likely to have a greater environmental risk (Chen et al., 2006). AragónCorrea et al. (2008) also indicated that size is a relevant factor to creating proactive environmental strategy, but size is not a determining condition to developing environmental management. Therefore, in this study, we propose the following hypotheses:

$\mathrm{H}_{1 \mathrm{a}}$ : Enterprise size has a positive effect on environmental (green) logistics awareness.

$\mathrm{H}_{1 \mathrm{~b}}$ : Enterprise size has a positive influence on proactive environmental (green) logistics strategy.

\section{Green awareness and green strategy hypothesis}

If an enterprise has green logistics awareness, then it is easy to understand that the enterprise may also need a proactive green logistics strategy and green logistics practices. As some authors have indicated, green awareness is the key element of a green strategy. LópezGamero et al. (2010) found that if the environmental strategies are drive from green awareness, and are not driven from legislation, then their effect on environmental management is significantly positive. Hart and Ahuja (1996) demonstrated that firms with that have an early awareness may be opting for more advanced environmental strategies that build on low emissions. Sarkis (2006) indicated that enterprises that develop an early strategy in pollution-reducing processing equipment benefit from a higher profit growth than later followers. This implies that firms implemented green awareness into better environmental programs and strategies will have better environmental performance. These concepts lead to the formulation of the following hypotheses:

$\mathrm{H}_{2 \mathrm{a}}$ : There is a positive relationship between green logistics awareness and green logistics strategy.

$\mathrm{H}_{2 b}$ : Green logistics awareness has a positive effect on green logistics management.

$\mathrm{H}_{2 c}$ : Green logistics awareness has a positive effect on business performance.

$\mathrm{H}_{3 \mathrm{a}}$ : Proactive green logistics strategy has a positive influence on green logistics management.

$\mathrm{H}_{3 \mathrm{~b}}$ : Proactive green logistics strategy has a positive influence on business performance.

\section{Green logistics management hypothesis}

As previously discussed, extensive literature has examined the relationship between green management and business performance; however, these studies have yielded no conclusive results. Some authors have showed a positive relationship between these concepts (Wu et al., 2010; Zeng et al., 2010). Other authors have showed a negative relationship (Cordeiro and Sarkis, 1997; Wanger, 2005). Although the results are mixed, research that has demonstrated a positive relationship between "green management (not green logistics)" and performance is found to be predominant. It is interesting to note that all studies published after the year 2005 (Table 1) showed the positive relationship. Thus, as the green issues become increasingly critical, green management is a key element to help an enterprise extract more value. In the light of these reasons, we propose the following hypothesis:

$\mathrm{H}_{4}$ : Green logistics management has a positive impact on the business performance.

Insights into these hypotheses provide us with a basis to make inferences on the relationship among those variables, as shown in Figure 1.

\section{METHODOLOGY}

\section{Sample and data collection}

Our sample and data was collected via internet questionnaires; we used the first self internet questionnaire website in China (http://www.taidu8.com). The respondent was asked to focus on the staff, section chief, and manager of the logistics enterprise. This questionnaire started in May 2010, and it was completed in September 2010. A total of 137 copies of the questionnaires were collected and 98 copies of the questionnaires provided all of the information required (these questionnaires came from different areas of China). The 98 logistics enterprises represent the various kinds of operational areas: $19.2 \%$ are in the integrated logistics sector, $13.7 \%$ are in the transportation sector, $14.3 \%$ are in the storage sector, $6.0 \%$ are in the packing sector, $6.6 \%$ are in the loading and unloading sector, $7.7 \%$ are in the logistics information sector, $5.5 \%$ are in the delivery sector, and the rest are in the manufacturing sector. The small- and medium-sized enterprises account for $79.6 \%$, large-sized enterprise account for $20.4 \%$.

\section{Measurement of the latent variables}

\section{Enterprise size}

The enterprise size was considered as a control variable to test our hypotheses, which predict that the business size has a positive effect on green logistics awareness and strategy. In this study, the firm's number of employees, capital sum, and gross sales of 2009 were selected to measure firm size as Choi et al. (2010) suggested. Table 2 shows the frequency and measures of enterprise size in this paper.

\section{Green logistics awareness}

Following the guidance of authors such as López-Gamero et al. (2010), we used 6 items (a1 to a6) to measure green logistics awareness in terms of self-perception of the firms' managers including awareness of the government's green policies, mindfulness of being green mind, knowledge about being green, the behavior of staff, green standardization, and green training. Each item is 


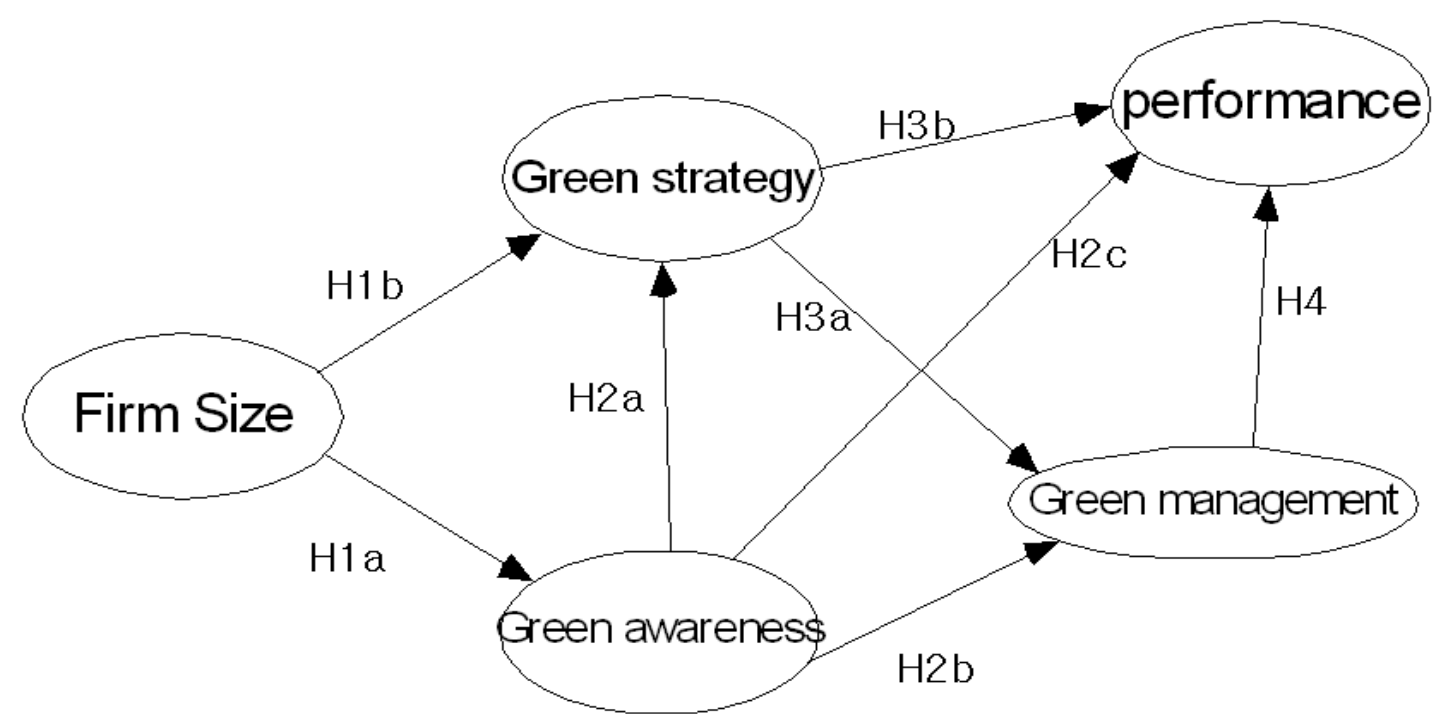

Figure 1. Research hypotheses and structural model.

Table 2. Enterprise size measures and frequency.

\begin{tabular}{llccc}
\hline Size measure & & Frequency & Percent & Question measure \\
\hline \multirow{3}{*}{ Capital sum* } & 5 million below & 52 & 53.1 & 1 \\
& $5-50$ million & 31 & 31.6 & 2 \\
& 50 million -100 million & 8 & 8.2 & 3 \\
& Over 100 million & 7 & 7.1 & 4 \\
& & & & \\
Gross sales* & 5 million below & 41 & 41.8 & 1 \\
& 5 - 50million & 36 & 36.7 & 2 \\
& 50million - 100 million & 10 & 10.2 & 3 \\
Employee & Over 100 million & 11 & 11.2 & \\
& & & & 1 \\
& 50 below & 41 & 41.8 & 2 \\
\hline
\end{tabular}

*Measured in RMB Yuan.

measured on a 7-point Likert response scale $(1=$ strongly disagree, 7 = strongly agree).

\section{Green logistics strategy}

Zhu et al. (2005) emphasized green logistics "strategy." In this study, 9 items (s1 to s9) are used to measure the green logistics strategy of firms. Some of the items included strategies on standardization, infrastructure, emissions reduction, technological management, and sustainability; they were measured using a 7-point Likert scale also.

\section{Green logistics management}

Green logistics management refers to detailed environmental logistics practices on different types of logistics process. Although many previous studies used various variables for environmental management, no studies have suggested measures for green logistics management. In this study, 20 detailed items are selected in relation to the different logistics processes. These items included information sharing ( $\mathrm{m} 1$ to $\mathrm{m} 3$ ), packing ( $\mathrm{m} 4$ to $\mathrm{m} 6)$, warehousing (m7 to $\mathrm{m} 9$ ), distribution (m10 to $\mathrm{m} 12$ ), loading and unloading (m13 to $\mathrm{m} 14$ ), logistics networking ( $\mathrm{m} 15$ to $\mathrm{m} 17$ ), and emissions reduction (m18 to m20). We used a 7-point Likert scale to measure the items too.

\section{Business performance}

Previous studies focused only on environmental performance (Szymanski and Tiwari, 2004; Zhu and Sarkis, 2004) or only on financial performance (Wanger et al., 2002; Wanger, 2005; Zeng et al., 2010). In this paper, we integrate both items including environmental performance (green image gain and green service level-up) and financial performance (sales increase and energy cost 
Table 3. Descriptive statistics and correlations of latent variables.

\begin{tabular}{lccccccc}
\hline Statistics & Mean & Std. Dev. & Awareness & Strategy & Management & Performance & Size \\
\hline Awareness & 4.099 & 1.500 & 1.000 & & & & \\
Strategy & 4.235 & 1.496 & 0.922 & 1.000 & & & \\
management & 4.459 & 1.407 & 0.879 & 0.949 & 1.000 & & \\
performance & 4.273 & 1.534 & 0.828 & 0.882 & 0.913 & 1.000 & \\
Size & 1.796 & 0.770 & 0.070 & 0.089 & 0.130 & 0.143 & 1.000 \\
\hline
\end{tabular}

Table 4. Reliability and validity test by the Cronbach's a and CFA.

\begin{tabular}{lcccccc}
\hline Variables & Cronbach's $\boldsymbol{\alpha}$ & Chi-square/df $(\mathbf{p})$ & GFI & NFI & CFI & RMSEA \\
\hline Green awareness & 0.952 & $1.627(0.11)$ & 0.962 & 0.982 & 0.993 & 0.080 \\
Green strategy & 0.974 & $1.303(0.18)$ & 0.956 & 0.983 & 0.996 & 0.056 \\
Green management & 0.984 & $1.628(0.10)$ & 0.962 & 0.984 & 0.994 & 0.080 \\
Business performance & 0.965 & $1.915(0.15)$ & 0.980 & 0.992 & 0.996 & 0.077 \\
Recommended criteria & $>0.7$ & $<3(>0.05)$ & $>0.9$ & $>0.9$ & $>0.9$ & $<0.08$ \\
\hline
\end{tabular}

reduction) to represent sustainable performance.

All the details in our questionnaire items for the proxy variables can be found in Appendix 1. Table 3 shows the descriptive statistics and correlations of the five latent variables. Since each of the correlations of the five variables is smaller than the corresponding calculated Cronbach's coefficients in Table 4, the composite index of variables are acceptable for further analysis (López-Gamero et al., 2009).

\section{RESULTS}

\section{Reliability and validity}

The proposed model must be statistically reliable and valid, so it can reflect reality, and we must ensure that the statistical results are meaningful. A positive result for the reliability test implies that the proposed method reflects similar results when tested again under the same conditions. For the reliability test, we used the Cronbach's $\alpha$ coefficient, which is the most commonly used criterion to measure reliability.

Validity refers to the extent to which items reveal true information. A confirmatory factor analysis (CFA) is one of the most effective tools to test the validity (Zeng et al., 2010). SPSS 17.0 and Amos 17.0 were used to test the reliability and validity, respectively. The results were demonstrated in Table 4. For the reliability, the Cronbach's coefficients are bigger than suggested, 0.7 , and for the validity test, the CFA measures, such as Chi-square/df , GFI (goodness-of-fit index), NFI (normalized fit index), CFI (comparative fit index), and RMSEA (root mean square error of approximation) are all better than the recommended criteria. This indicates that the reliability and validity of the data are good. The Cronbach's $\alpha$ and the confirmatory factor loadings of each item can be found in Appendix 1.

\section{Hypotheses test results}

The Amos 17.0 package was employed to run our structural equation modeling using the maximum likelihood (ML) approach. The overall fitness of the SEM is evaluated using the same set of goodness of fit indices used for the confirmatory factor analysis; Chi-square / $\mathrm{df}=2.029$, $\mathrm{GFI}, \mathrm{NFI}$, and $\mathrm{CFI}$ are all bigger than 0.9, which suggests that the SEM fits the data adequately. All of the SEM modeling and path coefficients are shown in Figure 2 and Table 5. The results show that $\mathrm{H}_{1 \mathrm{a}}$ and $\mathrm{H}_{1 \mathrm{~b}}$ are rejected; thus, there is no significant relationship between enterprise size and green awareness or size and green strategy. For green awareness, the results indicate that green awareness has a significant positive relationship ( $p$ $<0.01$ ) with green strategy, thus supporting $\mathrm{H}_{2 a}$; but has no relations with green practices. Also there is no relationship between green awareness and business performance, so we must reject $\mathrm{H}_{2 b}$ and $\mathrm{H}_{2 c}$. For the green strategy, the results show that the green strategy has a significant positive effect on green management $(p$ $<0.01$ ), accepting $\mathrm{H}_{3 a}$, but it has no significant impact on business performance, rejecting $\mathrm{H}_{3 \mathrm{~b}}$. Finally, there is a significant positive relationship between green management and business performance $(p<0.01)$; thus, we must accept $\mathrm{H}_{4}$.

\section{DISCUSSION}

\section{Managerial implications}

$\mathbf{H}_{1}$ : As for the issues of size, the results show that $\mathrm{H}_{1 a}$ and $\mathrm{H}_{1 \mathrm{~b}}$ were not supported. These results indicate that the enterprise size does not play a significant role on the green logistics awareness, enterprise size, and logistics 


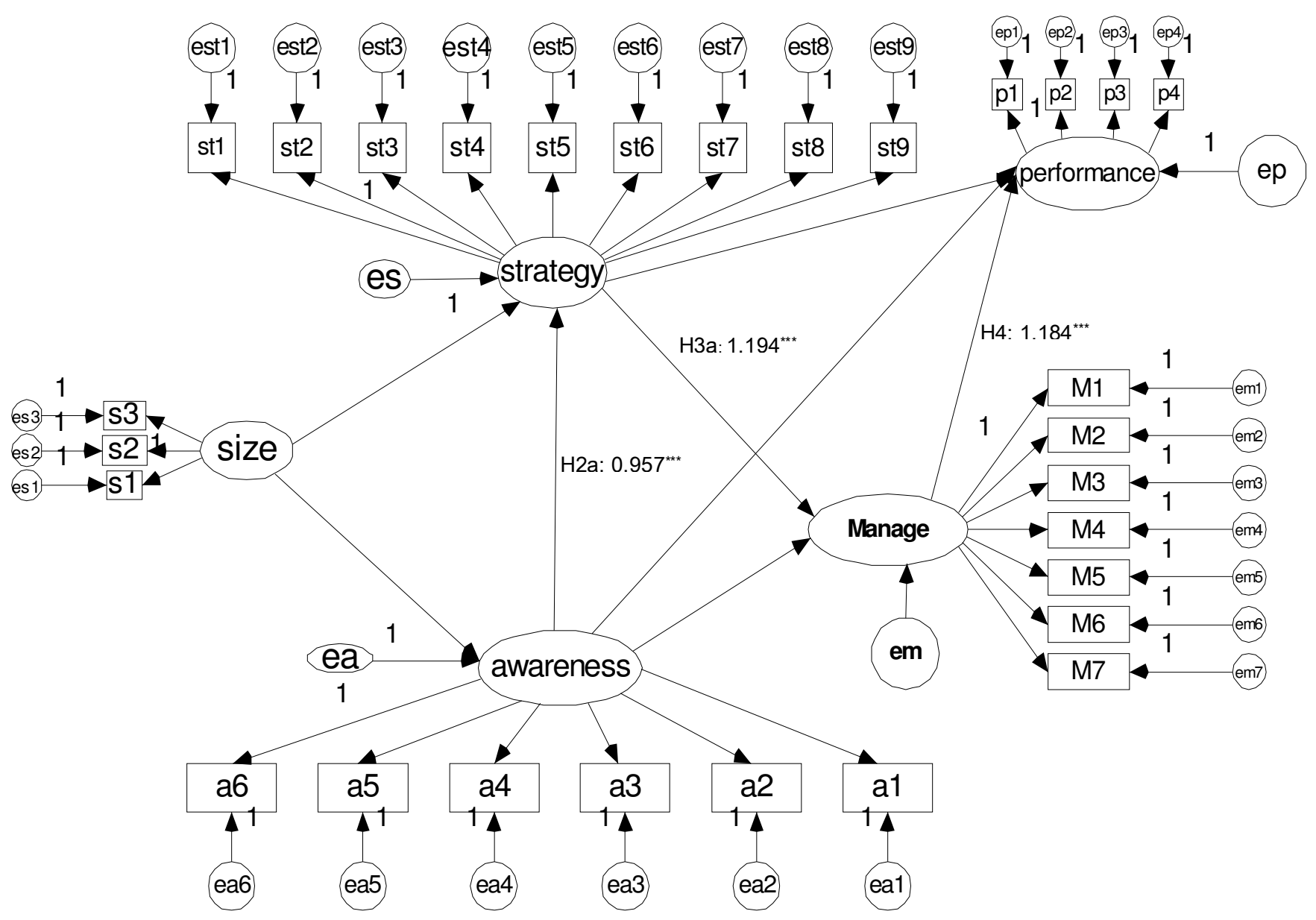

Figure 2. Path coefficients in the structural equation model.

${ }^{* * *}$ means $p<0.01$, size: firm size, strategy: green strategy, manage: green management, performance: business performance,s 1 s3,st1-st9,p1-p4,m1-m4,a1-a6: the observed variables for latent variables one may refers to the appendix 1 for more details, eses3,est1-est9,ep-ep4,em-em7,ea-ea6 : error terms.

Table 5. Results of the hypotheses test.

\begin{tabular}{|c|c|c|c|c|c|c|c|c|}
\hline \multicolumn{3}{|c|}{ Path relationship } & Path coefficient & S.E. & C.R. & $\mathbf{P}$ & Hypotheses & Result \\
\hline Awareness & $<--$ & size & 0.077 & 0.224 & 0.703 & 0.482 & $\mathrm{H}_{1 \mathrm{a}}$ & Reject \\
\hline Strategy & $<---$ & size & 0.052 & 0.078 & 1.316 & 0.188 & $\mathrm{H}_{1 \mathrm{~b}}$ & Reject \\
\hline Strategy & $<--$ & awareness & 0.957 & 0.077 & 12.05 & $* * *$ & $\mathrm{H}_{2 \mathrm{a}}$ & Accept \\
\hline Management & $<--$ & awareness & -0.233 & 0.173 & -1.241 & 0.215 & $\mathrm{H}_{2 b}$ & Reject \\
\hline Performance & $<--$ & awareness & 0.117 & 0.24 & 0.483 & 0.629 & $\mathrm{H}_{2 \mathrm{c}}$ & Reject \\
\hline Management & $<--$ & strategy & 1.194 & 0.195 & 5.78 & $* \star *$ & $\mathrm{H}_{3 \mathrm{a}}$ & Accept \\
\hline Performance & $<--$ & strategy & -0.351 & 0.472 & -0.753 & 0.452 & $\mathrm{H}_{3 \mathrm{~b}}$ & Reject \\
\hline Performance & $<--$ & management & 1.184 & 0.332 & 3.829 & $* * *$ & $\mathrm{H}_{4}$ & Accept \\
\hline
\end{tabular}

${ }^{* * *}$ means $p<0.01$.

green strategy. This result is different from previous studies. López-Gamero et al. $(2009,2010)$ found that larger firms tend to integrate the environmental strategy into their consideration better than smaller firms. Moore and Manring (2009) also suggest that larger enterprises are more likely to find that that their reputation suffers if they do not perform well on social measures, and these firms act accordingly. The results, however, indicate that green issues are not yet considered to be strategic elements of logistics enterprises in business practices in 
China. Green leadership could be emphasized in large logistics enterprises in China, but their leadership may not be compensated for corresponding performance.

$\mathbf{H}_{2}$ and $\mathbf{H}_{3}$ : As for the green awareness and strategy, the results indicate that green logistics awareness has a significant effect on green logistics strategy $\left(\mathrm{H}_{2 \mathrm{a}}\right)$. However, it has no significant impact on green logistics management $\left(\mathrm{H}_{2 b}\right)$. The green logistics strategy has a significant effect on green logistics management, which confirms $\mathrm{H}_{3 a}$; however, it has no significant effect directly on business performance, which rejects $\mathrm{H}_{3 \mathrm{~b}}$. These results indicate that green awareness does not have a direct effect on green management. However, it has an indirect effect on green management through its effect on green strategy. The empirical results imply that green awareness only cannot lead to field-oriented green practices in the enterprise, so the government should promote official environmental strategies or policies to the logistics enterprise to improve green logistics management. These implications agree with studies by Hitchens et al. (2003) and López-Gamero et al. (2010) in that green awareness by the governance legislation has a positive effect on environmental strategy. However, Hart and Ahuja (1996) demonstrated a different view that firms with early awareness may be opting for more advanced environmental management, which results in low emissions.

Sarkis (2006) indicated that an early strategy for pollution-reducing processing equipment offers more benefits with a higher profit growth than companies who are later planners. However, the findings in Table 5 indicate that the green strategy did not show a direct effect on business performance, but an indirect effect via its effect on green management. It implies that planning or strategies only cannot bring environmental benefits. The only factor that directly influences the business performance is the practice of green management.

$\mathbf{H}_{4}$ : The results show that there is a significant positive relationship between green logistics management and business performance. Thus, we can confirm $\mathrm{H}_{4}$. Our findings coincide with Rao and Holt (2005) and Wu et al. (2010); however, they disagree with Cordeiro and Sarkis (1997). Rao and Holt (2005) suggest that the enterprise with green supply chains may achieve a substantial cost savings, enhance sales, and exploit new market opportunities, which results in a better business performance.

Wanger (2005) also demonstrates that high levels of environmental performance are only possible if the enterprise's green management has a proactive technological pollution orientation. The results in Table 5 imply that from the empirical evidence of the logistics enterprises in China, it is necessary to adopt green practices as the key element in their business model to extract more value and enjoy better business competitiveness. These results also imply that the role of government promotion policies for green logistics is much more important for logistics enterprises to mold their strategies via their awareness
(Choi and Lee, 2009).

\section{Conclusion}

Previous studies about green management and its performance have focused mainly on manufacturing enterprises, and they have only focused on the partial relationship between the dichotomy of the business and the environment. This study aims to contribute to current literature by introducing a synthetic model that is based on structural equation modeling to test the causal relationship between green logistics management and business performance of the logistics sector in China. As a global factory, the role of the logistics network of China becomes more and more important. Thus, the synthetic analysis of diverse facets of green logistics related issues shall shed light on the paradigm for the logistics enterprises as well as the government promotion policies about the competition between green or sustainable logistics.

In this paper, we found that there are no significant roles of enterprise size in either the green awareness or green strategy. Thus, even large enterprises cannot utilize the economies of scale or leading advantages in logistics management. The result indicates that green awareness has a significant positive relationship with the green strategy, but has no relationship to green management and business performance; this suggests that green awareness only cannot lead to detailed green practices in the enterprise. It implies that the Chinese logistics enterprises are generally in the initial stage of green logistics because even though they are aware of the importance of green logistics, they are eager to apply these ideas to their business practices. Therefore, the government must promote the official environmental strategy or planned policy for the logistics industry. Also, the results show that the green strategy has a significant positive effect on green management, and there is a significant positive relationship between green management and business performance as well. It shows the spirit of strong pragmatism among the Chinese enterprises, suggesting that the green practices are the key element for the logistics enterprises to extract more value and to enjoy better business competitiveness.

\section{ACKNOWLEDGEMENTS}

This work was supported by the Korea Research Foundation Grant funded by the Korean Government (KRF-2008-005-J01602) and Inha University Research Grant.

\section{REFERENCES}

Ambec S, Lanoie P (2008). Does it pay to be green? A systematic overview. Acad. Manage. Exec., 22(4): 45-62. 
Aragón-Correa JA, Hurtado-Torres N, Sharma S, García-Morales VJ (2008). Environmental strategy and performance in small firms: A resource-based perspective. J. Environ. Manage., 86(1): 88-103.

Aronsson $\mathrm{H}$, Brodin $\mathrm{MH}$ (2006). The environmental impact of changing logistics structures. Int. J. Logist. Manage., 17(3): 394-415.

Chen SC, Li SH (2010). Consumer adoption of e-service: Integrating technology readiness with the theory of planned behavior. Afr. J. Bus. Manage., 4(16): 3556-3563.

Chen YS, Lai SB, Wen CT (2006). The influence of green innovation performance on corporate advantage in Taiwan. J. Bus. Ethics, 67(2): 331-339.

Choi $Y$ (2011). The efficiency of major ports under logistics risk in Northeast Asia. Asia-Pac J. Oper. Res., 28(1): 111-123.

Choi Y, Lee EY (2009). Optimizing risk management for the sustainable performance of the regional innovation system in Korea through metamediation. Hum. Ecol. Risk. Assess., 15(2): 270-280.

Choi Y, Lee EY, Wu DD (2010). The risk-effective sustainability of policies: The small business credit environment in Korea. Int. J. Environ. Pollut., 42(4): 317-329.

Cordeiro J, Sarkis J (1997). Environmental proactivism and firm performance: Evidence from security analyst earnings forecasts. Bus. Strateg. Environ., 6(1):104-114.

Hart S, Ahuja G (1996). Does it pay to be green? An empirical examination of the relationship between emission reduction and firm performance. Bus. Strateg. Environ., 5(1):30-37.

Heras-Saizarbitoria I, Molina-Azorín JF, Dick GPM (2011). ISO 14001 certification and financial performance: Selection-effect versus treatment-effect. J. Clean. Prod., 19(1):1-12.

Hitchens D, Clausen J, Trainor M, Keil M, Thankapan S (2003). Competitiveness, environmental performance, and management of SMEs. Green Manage. Int., 44(1): 45-57.

He LY, Fan Y, Wei YM (2009). Impact of Speculators' expectations of returns and time scales of investment on crude oil price behaviors. Energy Econ., 31(1): 77-84.

Huang PS, Shih LH (2010). The impact of industrial knowledge management and environmental strategy on corporate performance of ISO-14000 companies in Taiwan: The application of structural equation modeling. Afr. J. Bus. Manage., 4(1):21-30.

Chang NJ, Fong CM (2010). Green product quality, green corporate image, green customer satisfaction, and green customer loyalty. Afr. J. Bus. Manage., 4(13): 2836-2844.

Hussey DM, Eagan PD (2007). Using structural equation modeling to test environmental performance in small- and medium-sized manufacturers: Can SEM help SMEs? J. Clean. Prod., 15(4):303312.

King A, Lenox $M$ (2002). Exploring the locus of profitable pollution reduction. Manage. Sci., 48(2): 289-299.

Lee KH (2009). Why and how to adopt green management into business organizations? The case study of Korean SMEs in Manufacturing Industry. Manage. Decis., 47(7): 1101-1121.

Lee KH, Kim JW (2009). Current status of the supply management for CSR: The case of Korean electronics industry. Supply Chain Manage., 14(2): 138-148.

Link S, Naveh E (2006). Standardization and discretion: Does the environmental standard ISO 14001 lead to performance benefits? IEEE Trans. Eng. Manage., 53(4): 508-519.

López-Gamero MD, Molina-Azorín JF, Claver-Cortés E (2009). The whole relationship between environmental variables and firm performance: Competitive advantage and firm resources as mediator variables. J. Environ. Manage., 90(10): 3110-3121.
López-Gamero MD, Molina-Azorín JF, Claver-Cortés E (2010). The potential of environmental regulation to change managerial perception, environmental management, competitiveness, and financial performance. J. Clean. Prod., 18(10/11): 963-974.

Melnyk S, Sroufe R, Calanone R (2003). Assessing the impact of environmental management systems on corporate and environmental performance. J. Oper. Manage., 21(3): 329-351.

Menguc B, Ozanne $L$ (2005). Challenges of the "green imperative": A natural resource-based approach to the environmental orientation ebusiness performance relationship. J. Bus. Res., 58(4): 430-438.

Moore SB, Manring SL (2009). Strategy development in small and medium sized enterprises for sustainability and increased value creation. J. Clean. Prod., 17(2): 276-282.

Murphy PR, Poist RF (1995). Role and relevance of logistics to corporate environmentalism: An empirical assessment. Int. J. Phys. Logist. Manage., 25(2): 122-131.

Rao P, Holt D (2005). Do green supply chains lead to competitiveness and economic performance? Int. J. Oper. Prod. Manage., 25(2): 898916.

Russo M, Fouts $P$ (1997). A resource-based perspective on corporate environmental performance and profitability. Acad. Manage. J., 40(4): 534-559.

Sarkis J (2006). The adoption of environmental and risk management practices: Relationships to environmental performance. Ann. Oper. Res., 145: 367-381.

Szymanski M, Tiwari P (2004). ISO 14001 and the reduction of toxic emissions. Pol. Reform., 17(1): 31-42.

Wagner M (2005). How to reconcile environmental and economic performance to improve corporate sustainability: corporate environmental strategies in the European paper industry. J. Environ. Manage., 76(1): 105-118.

Wagner M, Van Phu N, Azomaou T, Wehrmeyer W (2002). The relationship between the environmental and economic performance of firms: An empirical analysis of the European paper industry. Corp. Soc. Responsib. Environ. Manage., 9(1): 133-146.

Wahba $H$ (2008). Does the market value corporate environmental responsibility? An empirical examination. Corporate Social Responsibility and Environmental Management. Corp. Soc. Responsibility Environ. Manage., 15(2): 89-99.

Wu GC, Cheng YH, Huang SY (2010). The study of knowledge transfer and green management performance in green supply chain management. Afr. J. Bus. Manage., 4(1): 44-48.

Zeng XS, Meng XH, Yin HT, Tam CY, Sun L (2010). Impact of cleaner production on business performance. J. Clean. Prod., 18(11): 975983.

Zhou P, Ang BW, Poh KL (2008). Measuring environmental performance under different environmental DEA technologies. Energy Econ. 30(1):1-14.

Zhu Q, Sarkis J (2004). Relationships between operational practices and performance among early adopters of green supply chain management practices in Chinese manufacturing enterprises. J. Oper. Manage., 22(3): 265-289.

Zhu Q, Sarkis J, Geng Y (2005). Green supply chain management in China: Pressures, practices and performance. Int. J. Oper. Prod. Manage., 25(5): 449-468. 


\section{APPENDIX}

Appendix 1: Measures of observed variables

\begin{tabular}{lcccc}
\hline Green awareness item & $\begin{array}{c}\text { Indicator in } \\
\text { Figure 2 }\end{array}$ & $\begin{array}{c}\text { Cronbach's } \\
\boldsymbol{\alpha}\end{array}$ & $\begin{array}{c}\text { Factor } \\
\text { loadings }\end{array}$ & \begin{tabular}{c} 
Mean \\
\hline $\begin{array}{l}\text { Your firm follows government policy on green } \\
\text { Logistics actively }\end{array}$
\end{tabular} \\
$\begin{array}{l}\text { The managers of firm pay close attention to green } \\
\text { Logistics }\end{array}$ & $\mathrm{a} 1$ & 0.832 & 0.904 & 3.867 \\
$\begin{array}{l}\text { The managers of firm have a good knowledge on } \\
\text { green logistics such as carbon footprint }\end{array}$ & $\mathrm{a} 2$ & 0.904 & 0.906 & 4.051 \\
$\begin{array}{l}\text { The staff has a good awareness of } \\
\text { green logistics }\end{array}$ & $\mathrm{a} 3$ & 0.932 & 0.917 & 4.143 \\
$\begin{array}{l}\text { The firm follows green standardization well such as ISO 14001 and GRI } \\
\text { guidelines }\end{array}$ & $\mathrm{a} 4$ & 0.926 & 0.907 & 4.173 \\
$\begin{array}{l}\text { The firm pays close attention to green training } \\
\text { formp }\end{array}$ & $\mathrm{a} 5$ & 0.903 & 0.851 & 4.296 \\
& $\mathrm{a} 6$ & 0.905 & 0.758 & 4.061
\end{tabular}

for employees

\section{Green strategy item}

Your firm takes great effort on logistics standardization

The firm takes effort on plan of green infrastructure

$\begin{array}{lcll}\text { St1 } & 0.86 & 0.867 & 4.194 \\ \text { St2 } & 0.925 & 0.921 & 4.204 \\ \text { St3 } & 0.929 & 0.926 & 4.265 \\ \text { St4 } & 0.942 & 0.945 & 4.143 \\ \text { St5 } & 0.899 & 0.862 & 4.235 \\ \text { St6 } & 0.939 & 0.912 & 4.194 \\ \text { St7 } & 0.861 & 0.837 & 4.357 \\ & & & \\ \text { St8 } & 0.887 & 0.858 & 4.306 \\ \text { St9 } & 0.936 & 0.939 & 4.214\end{array}$

The firm takes effect on strengthening green infrastructure

The firm takes effort on control of pollution sources in logistics activities

The firm plans Integrated distribution

The firms takes great effort on logistics technological research

The firms takes great effort on technological

standardization in logistics

The firms take many activities in logistics standardization

The firms take great effort on green marketing and green business

management

\section{Business performance item}

Financial performance: Through green logistics management, cost decreases as a result of energy savings

Financial performance: Return on Sales is significantly increased through green logistics management

Environmental performance: The green brand image is increased by green logistics management

Environmental performance: Green service satisfaction level improved by green logistics management

$\begin{array}{llll}\text { P1 } & 0.949 & 0.932 & 4.306 \\ \text { P2 } & 0.958 & 0.939 & 4.306 \\ \text { P3 } & 0.961 & 0.951 & 4.306 \\ \text { P4 } & 0.94 & 0.921 & 4.306\end{array}$

\begin{tabular}{|c|c|c|c|c|c|}
\hline Catalog & Green management & & & & \\
\hline \multirow{3}{*}{ Information sharing } & $\begin{array}{l}\text { The firm shares information with } \\
\text { manufacturing firms and retailers } \\
\text { well }\end{array}$ & M1 & 0.841 & 0.895 & 4.153 \\
\hline & $\begin{array}{l}\text { The firm makes great effort on } \\
\text { efficient and accurate ordering } \\
\text { system }\end{array}$ & & 0.876 & 0.929 & 4.439 \\
\hline & $\begin{array}{l}\text { The firm takes effort on outsourcing } \\
\text { to cut costs }\end{array}$ & & 0.813 & 0.868 & 4.286 \\
\hline
\end{tabular}


Appendix 1. Contd.

\begin{tabular}{|c|c|c|c|c|c|}
\hline \multirow{3}{*}{ Packing } & $\begin{array}{l}\text { The firm use green packing } \\
\text { materials }\end{array}$ & \multirow{3}{*}{ M2 } & 0.91 & 0.931 & 4.357 \\
\hline & $\begin{array}{l}\text { The firm follows packing } \\
\text { standardization }\end{array}$ & & 0.888 & 0.862 & 4.418 \\
\hline & $\begin{array}{l}\text { The firm makes effort on } \\
\text { reducing packing material } \\
\text { amount }\end{array}$ & & 0.903 & 0.928 & 4.357 \\
\hline \multirow{3}{*}{ Warehouse } & $\begin{array}{l}\text { The firm emphasizes } \\
\text { warehouse's efficient } \\
\text { management }\end{array}$ & \multirow{3}{*}{ M3 } & 0.864 & 0.903 & 4.653 \\
\hline & $\begin{array}{l}\text { The firm emphasizes the } \\
\text { reduction of warehouse fee }\end{array}$ & & 0.877 & 0.895 & 4.673 \\
\hline & $\begin{array}{l}\text { The firm emphasizes the } \\
\text { location selection of } \\
\text { warehouse }\end{array}$ & & 0.886 & 0.929 & 4.602 \\
\hline \multirow{3}{*}{ Transportation } & $\begin{array}{l}\text { The firm pushes the } \\
\text { standardization of transport }\end{array}$ & \multirow{3}{*}{ M4 } & 0.888 & 0.868 & 4.786 \\
\hline & $\begin{array}{l}\text { The firm tries to optimize the } \\
\text { routing of vehicles }\end{array}$ & & 0.897 & 0.931 & 4.633 \\
\hline & $\begin{array}{l}\text { The firm tends to select } \\
\text { greener vehicles and greener } \\
\text { transport modes such as } \\
\text { shipping and air }\end{array}$ & & 0.857 & 0.862 & 4.306 \\
\hline \multirow[b]{2}{*}{$\begin{array}{l}\text { Loading and } \\
\text { unloading }\end{array}$} & $\begin{array}{l}\text { The firm focuses on loading } \\
\text { and unloading efficiently }\end{array}$ & & 0.824 & 0.928 & 4.276 \\
\hline & $\begin{array}{l}\text { In order to improve efficiency, } \\
\text { the firm considers the } \\
\text { container or pallet }\end{array}$ & M5 & 0.878 & 0.903 & 4.480 \\
\hline \multirow{3}{*}{ Logistics networking } & $\begin{array}{l}\text { The firm pays attention to } \\
\text { construction of logistics } \\
\text { networking }\end{array}$ & \multirow{3}{*}{ M6 } & 0.913 & 0.895 & 4.571 \\
\hline & $\begin{array}{l}\text { The firm emphasizes } \\
\text { information technology input } \\
\text { and usage }\end{array}$ & & 0.921 & 0.929 & 4.520 \\
\hline & $\begin{array}{l}\text { The firm pays attention to } \\
\text { efficient logistics information } \\
\text { network }\end{array}$ & & 0.913 & 0.862 & 4.531 \\
\hline \multirow{3}{*}{ Logistics emissions } & $\begin{array}{l}\text { The firm tries hard to reduce } \\
\text { the pollution emissions in } \\
\text { logistics activities }\end{array}$ & \multirow{3}{*}{$\mathrm{M7}$} & 0.859 & 0.928 & 4.388 \\
\hline & $\begin{array}{l}\text { The firm takes great effort to } \\
\text { reduce green house gas } \\
(\mathrm{GHG})\end{array}$ & & 0.86 & 0.903 & 4.367 \\
\hline & $\begin{array}{l}\text { The firm takes great effort to } \\
\text { save energy costing }\end{array}$ & & 0.853 & 0.863 & 4.388 \\
\hline
\end{tabular}

